Ann. Biol. anim. Bioch. Biophys., 1978, 18 (1), 137-141.

\title{
Biochemical studies of the macromolecular matrix of long bones in the Op/Orl mutant rat strain
}

\author{
par E. MOCZAR, S. BERENHOLC *, B. PHAN-DINH-TUY, A. M. ROBERT \\ Laboratoire de Biochimie du Tissu conjonctif, \\ Faculté de Médecine, Université Paris XII \\ 6, rue du Général Sarrail, 94000 Créteil, France \\ * Instifut de Biologie appliquée au Domaine de la Santé, \\ 45000 Orléans, France.
}

\begin{abstract}
Summary. The long bones of normal and Op/Orl mutant rats were incubated with ${ }^{14} \mathrm{C}$-glucose and fractionated by EDTA and urea extraction. The analytical results of the various extracts suggested an increase in structural glycoprotein content and a decrease in collagen solubility in the long bones of mutants. Significant differences were found in the organic matrix composition of male and female bones of the two strains. ${ }^{14} \mathrm{C}$-glucose incorporation was stronger in males than in females. The presence of a glycosaminoglycan different from the chondroitinesulfate was shown in males. Basic amino acid content (lysine, arginine, histidine) was clearly higher in the insoluble residue of male bones.
\end{abstract}

\section{Introduction.}

The Op/Orl mutant exhibits characteristic modifications of the long bones, tooth retention and other abnormalities (Moutier, Lamendin and Berenholc, $1973 a$; Moutier, Lamendin and Berenholc, 1973 b ; Lamendin, Moutier and Berenholc, 1973). Long bone modifications are similar to those seen in humans suffering from AlbersSchönberg disease (Berenholc, Moutier and Lamendin, 1974 ; Berenholc ef al., 1975). This appeared spontaneously in the CNRS breeding farm at Orléans (Moutier, Lamendin and Berenholc, 1973a; Milhaud et al., 1975).

We wish to report here some results on the macromolecular composition of the long bone organic matrix of the « fatty » rat and the Op/Orl mutant.

\section{Material and methods.}

Three-week old « fatty » and Op/Orl rats were obtained from the CNRS colony (Dr. Sabourdy). The tibia and the femurs were dissected and the muscles and cartilagenous parts removed. Male and female animals were treated separately ; 6 animals were used in each group. The bones of two animals were pooled for extraction. 
Bone extraction. The bones were washed in 0.9 p. $100 \mathrm{NaCl}$ solution and disintergrated in an Omnimixer tissue homogenizer. The disintergrated fraction was demineralized with three $0.1 \mathrm{M}$-EDTA extractions for 2 days and mechanical agitation at room temperature (EDTA extract). The insoluble residue was extracted by $8 \mathrm{M}$-urea solution containing $0.1 \mathrm{M}$-mercaptoethanol (urea extract). The EDTA and urea were removed by dialysis.

Incubation with ${ }^{14} \mathrm{C}$-glucose. The bones of each animal from 2 separate experiments were incubated in organ culture conditions for 16 hours in Eagle's solution confaining $50 \mu \mathrm{Ci}$ of ${ }^{14} \mathrm{C}$-glucose. The incubated bones were extracted in the same way as the non-incubated samples. Extract radioactivites were determined in an Intertechnique scintillation counter.

Analytical procedure. Proteins, hexosamines and hydroxyproline were determined according to Lowry et al. (1951), Blix (1948) and Bergman and Loxley (1963), respectively. Aminoacid analysis was carried out on a Technicon TSM1 automatic aminoacid analyzer after acid hydrolysis (constant boiling $\mathrm{HCl}$, vacuum-sealed tubes, $110^{\circ}$, $23 \mathrm{hrs}$ ). Glycosaminoglycans were separated from the pronase digest of the EDTA extracts on cellulose acetate strips as described (Breen ef al., 1970).

\section{Results and discussion.}

The analytical characteristics of the different extracts are given in table 1 . The total amount of extractible proteins (EDTA + urea extracts) is somewhat higher in

\section{TABLE 1}

Chemical composition and radioactivity $\left({ }^{14} \mathrm{C}-g\right.$ lucose incorporation)

of the different fractions of the long bones of the "fatty » rat and of its mutant Op/OrI

\begin{tabular}{|c|c|c|c|c|}
\hline & \multicolumn{2}{|c|}{ Mutant Op/Orl } & \multicolumn{2}{|c|}{ Fatty } \\
\hline & Female & Male & Female & Male \\
\hline \multicolumn{5}{|l|}{ EDTA extracts } \\
\hline $\begin{array}{l}\text { Rel. prot. content } \ldots \ldots \ldots \ldots \ldots \ldots \ldots \ldots \\
\text { Hydroxyproline }{ }^{*} \ldots \ldots \ldots \ldots \ldots \ldots \ldots \\
\text { Hexosamines }{ }^{*} \ldots \ldots \ldots \ldots \ldots \ldots \ldots \\
\text { Radioactivity (cpm/mg prot.) } \ldots \ldots \ldots \ldots\end{array}$ & $\begin{array}{l}6 \\
0.4 \\
2.8 \\
3900\end{array}$ & $\begin{array}{l}7 \\
0.4 \\
2.0 \\
4850\end{array}$ & $\begin{array}{r}6 \\
1.0 \\
2.8 \\
3800\end{array}$ & $\begin{array}{r}5 \\
1.1 \\
2.2 \\
4500\end{array}$ \\
\hline \multicolumn{5}{|l|}{ Urea extract } \\
\hline $\begin{array}{l}\text { Rel. prot. content } \ldots \ldots \ldots \ldots \ldots \ldots \ldots \\
\text { Hydroxyproline }{ }^{*} \ldots \ldots \ldots \ldots \ldots \ldots \ldots \\
\text { Hexosamines }{ }^{*} \ldots \ldots \ldots \ldots \ldots \ldots \\
\text { Radioactivity (cpm/mg prot.) } \ldots \ldots \ldots \ldots\end{array}$ & $\begin{array}{r}4 \\
4.0 \\
2.8 \\
3100\end{array}$ & $\begin{array}{r}4.5 \\
3.5 \\
2.9 \\
3800\end{array}$ & $\begin{array}{r}3.5 \\
5.0 \\
1.4 \\
3360\end{array}$ & $\begin{array}{r}3 \\
5.2 \\
1.5 \\
3700\end{array}$ \\
\hline \multicolumn{5}{|l|}{ Residue } \\
\hline $\begin{array}{l}\text { Rel. prot. content } \ldots \ldots \ldots \ldots \ldots \ldots \ldots \\
\text { Hydroxyproline }{ }^{*} \ldots \ldots \ldots \ldots \ldots \ldots \ldots \ldots \\
\text { Hexosamines }{ }^{*} \ldots \ldots \ldots \ldots \ldots \ldots \ldots \\
\text { Sulphate ash }{ }^{*} \ldots \ldots \ldots \ldots \ldots \ldots \ldots\end{array}$ & $\begin{array}{l}90 \\
10 \\
0.5 \\
32\end{array}$ & $\begin{array}{c}88.5 \\
9.6 \\
0.55 \\
28\end{array}$ & $\begin{array}{r}91.5 \\
10.1 \\
0.3 \\
22.6\end{array}$ & $\begin{array}{r}92.0 \\
9.8 \\
0.2 \\
22.0\end{array}$ \\
\hline
\end{tabular}

* Hydroxyproline, hexosamines and ash are expressed as p. 100 of the protein content of each fraction. 
the mutants than in the original strains (10 to 11.5 p. 100 of total proteins as against 8 to 9.5 p. 100). The sulphate ash content of the extraction residues is alsohigher in the mutant than in the original strain. These results are in agreement with the more compact appearance of the mutant bones which have no or rare medullar cavities. The EDTA and urea extracts of the mutant bones contain less hydroxyproline, indicating increased insolubilization of the collagens in the more strongly calcified matrix. The urea extract and the insoluble residue of the mutant bones are significantly richer in hexosamines than the bones of the original strain. As the urea extracts were practically free of uronic acids, the high hexosamine content may be attributed to the presence of an increased amount of structural glycoproteins in the mutant bones.

Most of the proteoglycans were extracted by the EDTA solution. Cellogel electrophoresis of the pronase digest of these fractions indicated the presence of an alcian blue-positive substance, migrating as chondroitin sulphate. However, in the bones of the males of both strains (fatty and Op/Orl), small quantities (about 1/10 of the chondroitin sulfate) of a hyaluronic acid-like substance were also detected. Most of the proteins (88 to 92 p. 100) remained in the insoluble residue. The organic fraction of this residue consisted essentially of collagen, as indicated by the aminoacid analysis (tabl. 2). The aminoacid composition of the residues of the fatty and Op/Orl animals did not differ significantly. However, the residues of the male bones differed in some respect from those of female bones, i.e. the male bones were richer in basic aminoacids and poorer in proline. This finding may be explained by the presence of non-collagenous proteins associated to insoluble collagen in the male bones.

TABLE 2

Aminoacid composition of the insoluble residues of the long bones of the «fotty » rat and of the mutant $O p / O r l$. Residue $/ 100$ residues

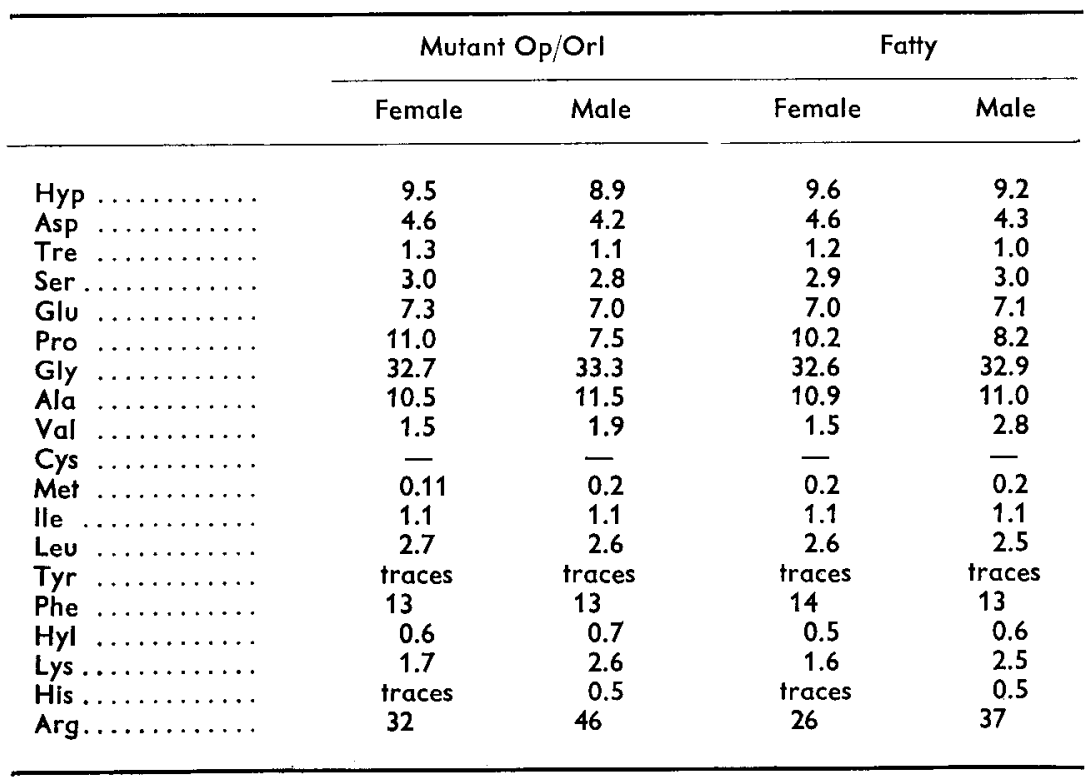


The divergences found in the hydroxyproline and hexosamine contents of the soluble bone fractions (EDTA and urea extracts) of fatty and $O_{P} / O r l$ rats indicate differences between the mutant and the original strain as to non-collagenous matrix proteins (carboxyglutamic acid-containing proteins) (Hauschka, Lian and Gallop, 1975 ; Price et al., 1976) and glycoproteins (Andrews, Herring and Kent, 1967 ; Shetlar, Hern and Chien su Fang, 1972).

Significant sex-related differences were detected in bone biosynthetic activity, as shown by the variation of ${ }^{14} \mathrm{C}$-glucose incorporation in the soluble bone fractions (EDTA and urea extracts, tabl 1). Such differences were also demonstrated in the glycosaminoglycan composition of the EDTA extract and in the aminoacid composition of the insoluble residue.

Réunion Groupe Développement INRA/Productions animales Montpellier, 17-18 mai 1977.

Acknowledgements. - This work was supported by the CNRS (ER 53) and ATP CNRS 5-406.

Résumé. Les os longs de rats normaux ef de mutant op/ori ont été incubés avec du ${ }^{14} \mathrm{C}$-glucose et soumis à une extraction fractionnée par l'EDTA et par l'urée. Les résultats d'analyse des différents extraits suggèrent une augmentation de la quantité des glycoprotéines de structure et une diminution de la solubilité du collagène dans les os des mutants.

Des différences significatives ont été démontrées dans la composition de la matrice organique des os des mâles et des femelles des deux souches. L'incorporation du ${ }^{14} \mathrm{C}-\mathrm{glu}$ cose est plus forte chez les mâles que chez les femelles. La présence d'un glycosaminoglycanne acide a été démontrée en plus du chondroïtinesulfate chez les mâles. La teneur en acides a minés basiques (lysine, arginine, histidine) est nettement plus élevée dans le résidu insoluble des os chez les mâles.

\section{References}

ANDREWS A. T., HERRING G. M., KENT P. W., 1967. Some studies on the composition of bovine cortical-bone sialoprotein. Biochem. J., 104, 705-775.

BERENHOLC S., LAMENDIN H., GODEAU G., ROBERT A. M., 1975. Etude histologique des altérations osseuses chez le rat mutant «Op ». Actual. ondonto-stomat., 109, 119-128.

BERENHOLC S., MOUTIER R., LAMENDIN H., 1974. Maladie d'Albers-Schönberg et ostéopétrose chez un rat mutant. Congr. nat. Assoc. dentaire de France, 21 novembre.

BERGMANN I., LOXLEY R., 1963. Two improved and simplified methods for spectrophotometric determination of hydroxyproline. Analyt. Chem., 35, 1961-1963.

BLIX G., 1948. Determination of hexosamines according to Elson-Morgan, Acta chem. scand., 2, 467-472.

BREEN M., WEINSTEIN H. G., ANDERSEN M., VEIS A., 1970. Microanalysis and characterization of acidic glycosaminoglycans in human tissues. Analyt. Biochem., 35, 146-159.

HAUSCHKA P. V., LIAN J. B., GALLOP P. M., 1975. Direct indentification of the calcium-binding amino acid., carboxyglutamate, in mineralized tissue. Proc. nat. Acad. Sci., USA, 72, 3925-3929,

LAMENDIN H., MOUTIER R., BERENHOLC S., 1973. A propos de rats mutants « Op ». Symbioses. Orléans, 5, 205-217.

LOWRY O. H., ROSENBROUGH N. J., FARR L., RANDALL R. J., 1951. Protein measurement with the folin phenol reagent. J. biol. Chem., 193, 265-275.

MILHAUD G., LABAT M. L., GRAF B., JUSTER M., BALMAIN N., MOUTIER R., TOYAMA K., 1975. Démonstration cinétique, radiographique et histologique de la guérison de l'ostéopétrose congénitale du rat, $C$. R. Acad. Sci. Paris, Série $D, 280,2485-2488$. 
MOUTIER R., LAMENDIN H., BERENHOLC S., 1973a. Rétention héréditaire des dents chez le rat. Inf. dent., 11, 21-23.

MOUTIER R., LAMENDIN H., BERENHOLC S., 1973b. Ostéopétrose par mutation spontanée chez le rat. Expér. anim., 6, 87-101.

PRICE P. A., OTSUKA A. S., POSER J. W., KRISTAPONIS J., RAMAN N., 1976. Characterization of a -carboxyglutamic acid containing protein from bone. Proc. nat. Acad. Sci., USA, 73, 1447-1451. SHETLAR M. R., HERN D., CHIEN SU FANG, 1972. Isolation and characterization of human bone sialoprotein. Texas. Rep. Biol. Med., 30, 340-345. 